\title{
Tree species diversity and structural composition: The case of Durgapur Hill Forest, Netrokona, Bangladesh
}

\author{
MD. RAYHANUR RAHMAN ${ }^{1, \bullet}$, MD. MIZANUR RAHMAN ${ }^{1}$, MD. ARIF CHOWDHURY ${ }^{2, \bullet \bullet}$, JARIN AKHTER $^{1}$ \\ ${ }^{1}$ Institute of Forestry and Environmental Sciences, University of Chittagong. Room No. 412, Block-B, Masterda Surja Sen Hall, University of \\ Chittagong, Chittagong-4331, Bangladesh. •email: rayhanur.pavel@gmail.com \\ ${ }^{2}$ Institute of Water and Flood Management, Bangladesh University of Engineering and Technology. Dhaka, Bangladesh. "vemail: \\ arifchowdhury065@gmail.com
}

Manuscript received: 15 October 2018. Revision accepted: 10 February 2019.

\begin{abstract}
Rahman MdR, Rahman MdM, Chowdhury MdA, Akhter J. 2019. Tree species diversity and structural composition: The case of Durgapur Hill Forest, Netrokona, Bangladesh. Asian J For 3: 10-19. Hill forest in Durgapur, Netrokona District, Bangladesh has been rarely studied to reveal its biodiversity information. This study aimed to assess tree species diversity and structural composition based on diameter and height class distribution in Durgapur hill forest (DHF). Tree inventory using stratified random sampling method was conducted during the period of October 2017 to May 2018 by establishing 42 sample plots with each plot had $20 \mathrm{~m}$ x $20 \mathrm{~m}$ in size. A total of 1436 stems of $\geq 5 \mathrm{~cm}$ DBH of 56 tree species belonging to 50 genera and 29 families were enumerated from the sampled area. Stem density was $855 \mathrm{stem} \mathrm{ha}^{-1}$ and basal area was $29.27 \mathrm{~m}^{2} \mathrm{ha}^{-1}$. The Shannon-Wiener's, Margalef's, Simpson's and Pielou's diversity indices indicate that Durgarpur hill forest had a moderately diverse tree species and lower diversity in comparison to other natural forests of the country. The study showed that the most dominant 10 species have 58\% of the total IVI (174.29 out of 300) in which Acacia auriculiformis showed the maximum Importance Value Index (51.02) followed by Shorea robusta (24.23). Number of individual tree species was the highest (49) in the height range of 7- <12 m whereas maximum (52) species were recorded in the DBH (cm) range of 5- $<10 \mathrm{~cm}$. Acacia auriculiformis, Shorea robusta, and Tectona grandis were found as the most dominant species based on hierarchical cluster analysis. The current study will be helpful for policymakers in formulating forest resource management plan for Durgapur hill forest.
\end{abstract}

Keywords: Diversity indices, Durgapur hill forest, importance value index, phytosociological characters, structural composition

Abbreviations: DBH: Diameter at Breast Height, BBS: Bangladesh Bureau of Statistics, DHF: Durgapur hill forest, IFESCU: Institute of Forestry and Environmental Sciences, University of Chittagong, BFRI: Bangladesh Forest Research Institute, BA: Basal Area, D: Density, RD: Relative Density, F: Frequency, RF: Relative Frequency, A: Abundance, RA: Relative Abundance, Rdo: Relative Dominance, IVI: Importance Value Index, PSP: Permanent Sample Plot, ANR: Assist Natural Regeneration.

\section{INTRODUCTION}

The diversity of plant species and structural composition plays a significant role in maintaining the integrity of forest ecosystems (Sajib et al. 2016; Rahman et al. 2017). Tree species diversity can serve as a proxy or indicator of the general pattern of the broader biological diversity of a forest. For example, a higher number of tree species is associated with a higher number of understory plants, or even animal diversity. Therefore, information on floristic composition, quantitative structure and diversity of tree vegetation is vital for understanding the functioning and dynamics of forest ecosystems (Reddy et al. 2008; Hossain et al. 2015). Such information is essential for sustainable use and management activities of a forest.

Bangladesh is situated in a transition between India and Myanmar (often so-called Indo-Myanmar) region. Because of the unique geophysical characteristics, the country has rich biological diversity containing about 5700 species of angiosperms (Nur et al. 2016). However, the depletion of native species was accelerating at an alarming rate due to the rapid deforestation and forest degradation (Hossain
2001). During the last few decades, some areas of natural forest in Bangladesh have been degraded due to anthropogenic activities, primarily by land encroachment (Rahman et al. 2017).

Undisturbed natural hill forests of Bangladesh are generally uneven-aged and multi-storied (Alam 2008). One of biologically important regions in Bangladesh is Durgapur hill forest located in Netrokona District. The district shares border with Garo Hills of India to the north and the biggest haor (swampy land) area of Sunamganj District to the east. A large variety of plants, including trees, grow in the district. As Durgapur hill forest of Netrokona is close to inland sal forest of TangailMymensingh District, the species composition is almost similar in between the two districts whereas some of which are important for timber, such as sal (Shorea robusta), bot (Ficus benghalensis), tentul (Tamarindus indica), sada karoi (Albizzia procera), simul (Bombax ceiba) and aswatha (Ficus religiosa) (BBS 2013).

In government managed forests of Bangladesh, many researchers have investigated plant species diversity and forest stand structure (Nath et al. 1998; Nath et al. 2000; 
Motaleb and Hossain 2011; Hossain et al. 2013; Feeroz and Uddin 2015; Hossain et al. 2015; Chowdhury et al. 2018a, b; Das et al. 2018). Recently, a taxonomic study was done by Rahman et al. (2017) concentrating on the flora of Madhupur National Park under different genera and families. Also, a clear understanding of forest stands parameters, i.e., diameter and height class distribution, and forest stocking are important for management strategies (Hossain et al. 2017). However, such scientific efforts are lacking in Durgapur Hill Forest (DHF), especially to reveal information regarding structural composition, plant diversity and conservation issues. Hence, the present study is conducted in DHF of Bangladesh aiming to assess tree species diversity and structural composition based on diameter and height class distribution. The results of this study will serve as baseline information to monitor changes in species composition and to undertake conservation and management activity of the hill forest in the future.

\section{MATERIALS AND METHODS}

\section{Study area}

The study area is located in the most northern part of Durgapur at the coordinates of $25^{\circ} 7^{\prime} 30^{\prime \prime} \mathrm{N}$ and $90^{\circ} 41^{\prime} 18^{\prime \prime}$ E (Figure 1). Durgapur Upazila is a small city of Netrokona District, with an area of $293.42 \mathrm{~km}$ and consists of 7 unions. Durgapur is bordered by Meghalaya State of India to the north, Purbadhala and Netrokona Sadar to the south, Kalmakanda to the east, and Dhobaura sub-district to the west. There are three main rivers in Durgapur namely Old
Someshwari, Kangsa and Someshwari.

Topographically, the study area is characterized by its large hillocks, known as 'tilla' with irregular plain land. This area is located in the semi-drier part of Bangladesh. The highest temperature reaches $30^{\circ} \mathrm{C}$ during May and the coldest to around $10^{\circ} \mathrm{C}$ during January. The area has an average rainfall $2712 \mathrm{~mm}$ per year.

\section{Data collection}

Reconnaissance survey was conducted for planning of data collection with considerations of the accessibility of the forest, vegetation density and stratification, human settlement within the forest and fragmentation of the forest patches. Three transect walks across the study area were done.

The data collection was conducted from October 2017 to May 2018 to cover the whole study area. Stratified random sampling method was used for the inventory of the tree species. Sample plot with size of $20 \mathrm{~m} \times 20 \mathrm{~m}$ was determined by applying the species-area curve of Caratti (2006) where a total of 42 sample plots were taken purposively. Sample plots were determined based on the area of the respected forest. Plots were taken both in natural and plantation forest patches having low, medium and dense tree cover. Position of each sample plot was then recorded using Ground Positioning System (GPS) device. Area of each plot was demarcated by measuring tape and rope. Plants having $\mathrm{dbh} \geq 5 \mathrm{~cm}$ were recorded from the quadrats. Total height and diameter at breast height (dbh) of all trees inside the demarcated plots were measured using Suunto Clinometer and diameter tape respectively.
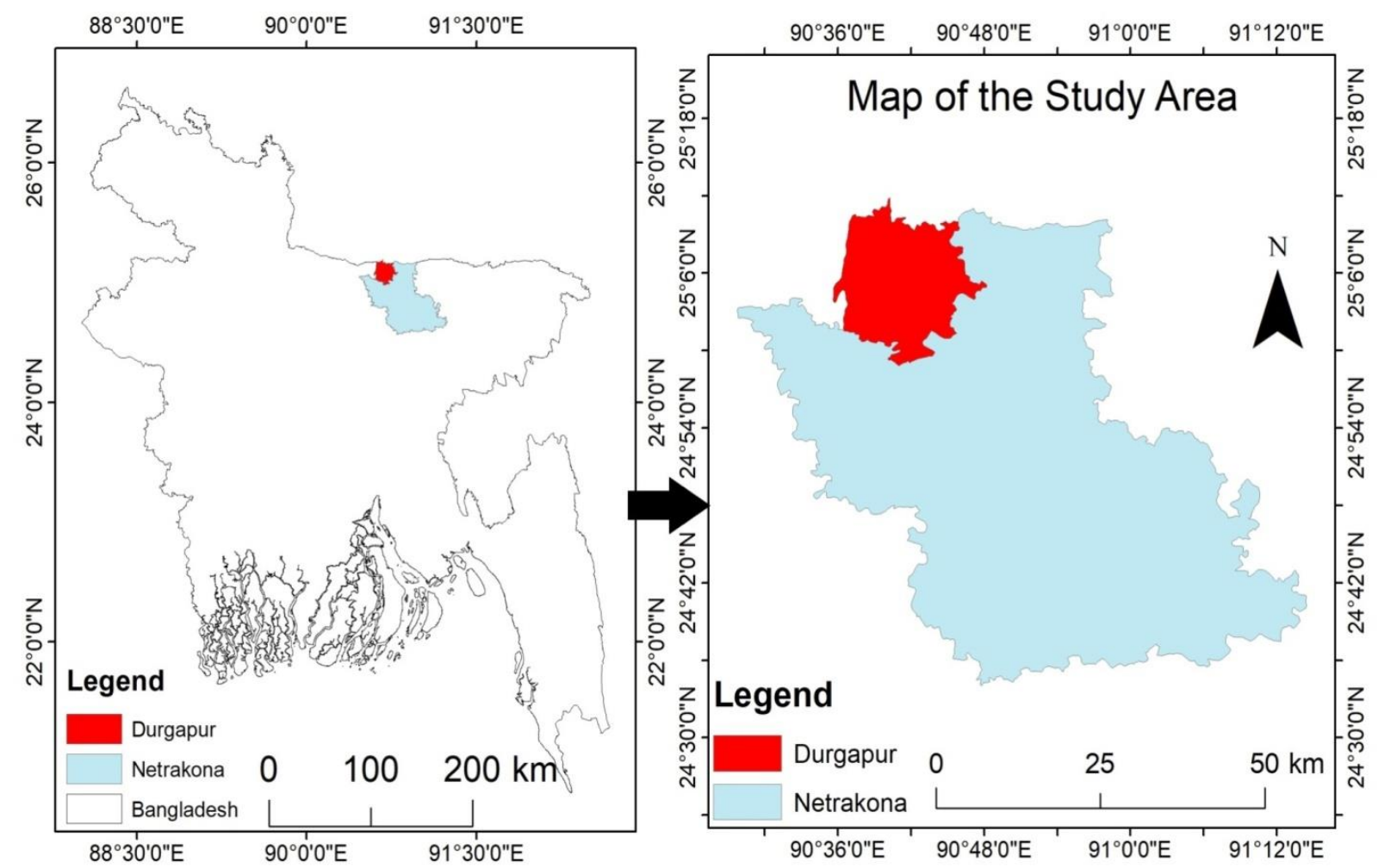

Figure 1. Map of the study area in Durgapur Upazila, Netrokona District, Bangladesh 
For multi-stemmed trees, the bole dbh was measured below the forking (if height is $1.3 \mathrm{~m}$ from the ground) with each stem was considered as individual tree. Standard scientific method of dbh measurement was followed in other critical situations, i.e., buttressed stem, leaned tree, slope, etc.

Common tree species were identified directly in the field, while the samples of the unknown tree species were collected for the preparation of herbarium specimens and later those specimens were dried in the sun following standard scientific method. Consultation was done with published journals and reference books like Siddiqui et al. (2007) and Encyclopedia of Flora and Fauna of Bangladesh (Ahmed et al. 2008). Taxonomists from the Institute of Forestry and Environmental Sciences, University of Chittagong (IFESCU) and the Bangladesh Forest Research Institute (BFRI) also helped with species identification. Besides, the author's own collections, the herbarium specimens previously collected from Madhupur National Park, Tangail were also examined (Rahman et al. 2017).

\section{Analysis of field data}

The field data were compiled and analyzed to determine the density, relative density (RD \%), frequency, relative frequency ( $\mathrm{RF} \%$ ), abundance, relative abundance (RA \%) and Importance Value Index (IVI). The equations used for calculating phytosociological characters are listed in Table 1 (Eq. No. 1-9). Besides, biodiversity indices such as Shannon's index, Simpson's diversity index, species evenness index, Margalef's index, etc., for the DHF were calculated and compared the findings with other studies in government managed forests of the country. The equations (Eq. No. 1-4) used for calculating biodiversity indices are listed in Table 2. Besides, hierarchical cluster analysis was done using computer software package SPSS.

Margalef's index (R) is high in communities that include a greater number of species and in which the number of individuals of each species decreases relatively slowly on passing from more abundant to less abundant ones (Margalef 1958). Shannon-Wienner diversity index value is maximum when the number of individuals of all species is equal; value is zero if there are only one species (Shannon-Wienner 1963). With Simpson's diversity index (D), 0 represents infinite diversity and 1, no diversity. Species Evenness index (E) also known as Shannon's equitable index, assumes a value between 0 and 1 with 1 being complete evenness (Pielou 1966).

Table 1. The list of equations used for calculating phytosociological characters of the vegetation

\begin{tabular}{|c|c|c|}
\hline Phytosociological attributes & Formula & References \\
\hline Basal area/ha (BA) & 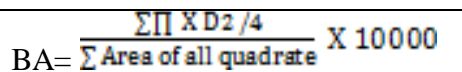 & $\begin{array}{l}\text { Shukla and Chandel (2000), Chowdhury et al. } \\
\text { (2018b) }\end{array}$ \\
\hline Density (D) & $\mathrm{D}=\frac{\bar{a}}{\bar{b}}$ & Shukla and Chandel (2000) \\
\hline Relative density (RD) & $\mathrm{RD}=\frac{\mathrm{n}}{\mathrm{N}} \times 100$ & Misra (1968), Dallmeier et al. (1992) \\
\hline Frequency $(\mathrm{F})$ & $\mathrm{F}=\frac{\bar{b}}{\mathrm{~b}}$ & Shukla and Chandel (2000) \\
\hline Relative frequency $(\mathrm{RF})$ & $\mathrm{RF}=\frac{F \mathrm{i}}{\sum_{\mathrm{f}=-2}^{\mathrm{i}}(\mathrm{Fi})}$ & Misra (1968), Dallmeier et al. (1992) \\
\hline Abundance (A) & $\mathrm{A}=\frac{\mathrm{n}}{\mathrm{e}}$ & Shukla and Chandel (2000) \\
\hline Relative abundance (RA) & $\mathrm{RA}=\frac{A \mathrm{Ai}}{\sum^{\Sigma}(\mathrm{Ai})}$ & Shukla and Chandel (2000) \\
\hline Relative dominance (D) & $\mathrm{RD}=\frac{\text { Basal area of onespecies }}{\text { Total basal area }} \times 100$ & Hossain et al. (2013), Chowdhury et al. (2018b) \\
\hline Importance Value Index (IVI) & $\mathrm{IVI}=\mathrm{RD}+\mathrm{RF}+\mathrm{RA}$ & $\begin{array}{l}\text { Dallmeier et al. (1992), Shukla and Chandel } \\
\text { (2000) }\end{array}$ \\
\hline
\end{tabular}

Table 2. The list of equations used for calculating biodiversity indices of the vegetation

\begin{tabular}{lll}
\hline Biodiversity indices & Formula & References \\
\hline Shannon-Wiener's diversity index (H) & $\mathrm{H}=\sum_{i=1}^{n} P_{i} \ln P_{i}$ & Shannon and Wiener (1963) \\
Margalef's species richness index (R) & $\mathrm{R}=\frac{(S-1)}{L N(N)}$ & Margalef (1958) \\
Simpson's diversity index (D) & $\mathrm{D}=\sum_{\mathrm{i}=1}^{n} P_{\mathrm{i}}^{2}$ & Simpson (1949) \\
Species (Pielou's) evenness index (E) & $\mathrm{E}=\frac{H}{\operatorname{Ln}(\Omega)}$ & Pielou (1966) \\
\hline
\end{tabular}

Note: $\mathrm{H}=$ Shannon-Wiener's diversity index, $\mathrm{N}=$ Total no. of individuals of all the species, $\mathrm{Pi}=$ Number of individuals of $\mathrm{i}^{\text {th }}$ species/Total number of individuals, $\mathrm{S}=$ Total number of species 


\section{RESULTS AND DISCUSSION}

\section{Results}

Tree species composition

Tree is a vital element of any forest. A total of 56 species belongs to 50 genera and 29 families were recorded from the forest area. Mimosaceae was the most dominant family with 7 species and 4 genera followed by Arecaceae (4 species and 4 genera), Euphorbiaceae with 4 species and 4 genera and Combretaceae, Meliaceae, Myrtaceae, Moraceae, Rutaceae, Sapotaceae with 3 species each (Table 3).

\section{Diversity indices}

A total of 1436 individual stems were recorded from the Durgapur hill forest. The vacant area of the forest was covered with more or less mixed and mono plantations. Therefore, high stem density (855 stem ha ${ }^{-1}$ ) was also found there. The Shannon-Wiener's index (3.18), species evenness index (0.79) Margalef's diversity index (7.57), and The Simpson's diversity index (0.07) was calculated for the study area (Table 4). The values of Shannon-Wiener and Margalef's diversity index indicate proficient presence of plant species in the area. Lower value of Simpson's index also stands for moderately diverse tree species.

\section{Phytosociological characters of the tree species}

Basal area, density, relative density, relative frequency, relative abundance, relative dominance and Importance Value Index (IVI) of the recorded tree species are shown in (Table 5). Fifteen dominant tree species accounted for $73.53 \%$ of the individuals (1056 out of 1436), $79.27 \%$ of the basal area, $73.53 \%$ of the relative density, $59.39 \%$ of the relative frequency, $54.05 \%$ of the relative abundance, $79.26 \%$ of the relative dominance and $68.53 \%$ of the IVI Highest IVI was found for Acacia auriculiformis (51.02) followed by Shorea robusta (24.23), Tectona grandis (22.86).

Table 3. List of tree species found in the DHF with family name

\begin{tabular}{|c|c|c|}
\hline Scientific name & Local name & Family \\
\hline $\begin{array}{l}\text { Acacia auriculiformis A. } \\
\text { Cunn. ex Benth. \& Hook }\end{array}$ & Akashmoni & Mimosaceae \\
\hline Acacia mangium Willd. & Mangium & Mimosaceae \\
\hline Aegle marmelos (L.) Corr. & Bel & Rutaceae \\
\hline $\begin{array}{l}\text { Albizia lebbeck (L.) Benth. \& } \\
\text { Hook }\end{array}$ & Kala Koroi & Mimosaceae \\
\hline Albizia procera (Roxb.) Benth. & Shilkoroi, & Mimosaceae \\
\hline $\begin{array}{l}\text { Albizia richardiana (Voigt.) } \\
\text { King \&Prain }\end{array}$ & Raj koroi & Mimosaceae \\
\hline Alstonia scholaris (L.) R. Br. & Chatian & Apocynaceae \\
\hline $\begin{array}{l}\text { Aphanamixis polystachya } \\
\text { (Wall.) R.N. Parker. }\end{array}$ & Pitraj & Mimosaceae \\
\hline Aporosa sp. & Kharjon & Euphorbiaceae \\
\hline Aquilaria agallocha Roxb. & Agar & Thymeliaceae \\
\hline Araucaria cunninghamii Sw. & Christmas tree & Araucariaceae \\
\hline Areca catechu $\mathrm{L}$. & Supari & Arecaceae \\
\hline Artocarpus heterophyllus Lamk. & Kanthal & Moraceae \\
\hline
\end{tabular}

\begin{tabular}{|c|c|c|}
\hline Artocarpus lacucha Buch.-Ham. & Borta & Moraceae \\
\hline Averrhoa carambola $\mathrm{L}$. & Kamranga & Oxalidaceae \\
\hline Azadirachta indica A. Juss. & Neem & Meliaceae \\
\hline $\begin{array}{l}\text { Barringtonia acutangula (L.) } \\
\text { Gaertn. }\end{array}$ & Hijal & Lecythidaceae \\
\hline Bischofia javanica Blume & Kanjalbhadi & Euphorbiaceae \\
\hline Bombax ceiba $\mathrm{L}$. & Shimul & Bombacaceae \\
\hline Borassus flabellifer $\mathrm{L}$. & Tal & Arecaceae \\
\hline Cassia fistula $\mathrm{L}$. & Sonalu & Caesalpiniaceae \\
\hline Chukrasia tabularis A. Juss. & Chickrassi & Meliaceae \\
\hline Cryptocarya amygdalina Nees. & Ojha & Lauraceae \\
\hline Dillenia scabrella Roxb. ex Wall. & Ajuli, Ajugi & Dilleniaceae \\
\hline Diospyros blancoi A. DC. & Bilati gab & Ebenaceae \\
\hline Elaeis guineensis Jacq. & Oil pulm & Arecaceae \\
\hline Eucalyptus camaldulensis Dehnh & Eucalyptus & Myrtaceae \\
\hline Ficus hispida L. f. & Dumor & Moraceae \\
\hline Gmelina arborea Roxb. & Gamar, Jogi & Verbenaceae \\
\hline Grewia nervosa (Lour.) Panigr. & Datoi & Tiliaceae \\
\hline $\begin{array}{l}\text { Haldina cordifolia (Roxb.) } \\
\text { Ridsdale }\end{array}$ & Kaika, haldu & Rubiaceae \\
\hline Lagerstroemia speciosa (L.) Pers & Jarul & Lythraceae \\
\hline Limonia acidissima $\mathrm{L}$. & Kodbel & Rutaceae \\
\hline Litchi chinensis Sonn. & Litchi & Sapindaceae \\
\hline $\begin{array}{l}\text { Madhuca longifolia (Koenig) } \\
\text { MacBride }\end{array}$ & Mahua & Sapotaceae \\
\hline $\begin{array}{l}\text { Mallotus philippensis (Lamk.) } \\
\text { Muell.-Arg. }\end{array}$ & Sinduri & Euphorbiaceae \\
\hline Mangifera indica $\mathrm{L}$. & Aan & Anacardiaceae \\
\hline $\begin{array}{l}\text { Manilkara zapota (L.) P. van } \\
\text { Royen }\end{array}$ & Sof & Sapotaceae \\
\hline Mimusops elengi L. & Bakul & Sapotaceae \\
\hline Moringa oleifera Lamk. & Sajna & Moringaceae \\
\hline Murraya paniculata (L.) Jack & Kamini & Rutaceae \\
\hline $\begin{array}{l}\text { Neolamarckia cadamba } \\
\text { (Roxb.) Bosser }\end{array}$ & Kadom & Rubiaceae \\
\hline Phoenix sylvestris Roxb. & Khejur & Are \\
\hline Phyllanthus emblica L. & Am & Euphorbiaceae \\
\hline Psidium guajava $\mathrm{L}$. & Pay & Myr \\
\hline $\begin{array}{l}\text { Pterospermum acerifolium } \\
\text { (L.) Willd. }\end{array}$ & Moos & Sterculiaceae \\
\hline Samanea saman (Jacq.) Merr. & Raintree & aceae \\
\hline Shorea robusta Roxb. ex Gaertn.f. & Sal & Dipterocarpacea \\
\hline Swietenia mahagoni Jacq. & Mahagoni & Meliaceae \\
\hline Syzygium cumini (L.) Skeels & Kalojam & Myrtaceae \\
\hline Tamarindus indica $\mathrm{L}$. & Tentul & Caesalpiniaceae \\
\hline Tectona grandis L. f. & Shegun & Verbenaceae \\
\hline $\begin{array}{l}\text { Terminalia arjuna (Roxb. ex } \\
\text { DC.) Wight \& Arn. }\end{array}$ & Arjun & Combretaceae \\
\hline $\begin{array}{l}\text { Terminalia bellirica (Gaertn.) } \\
\text { Roxb. }\end{array}$ & Bohera & Combretaceae \\
\hline Terminalia chebula Retz. & Har & retaceae \\
\hline Ziziphus mauritiana Lamk. & Boroi & Rhamnaceae \\
\hline
\end{tabular}

Table 4. Density and tree diversity indices of the DHF

\begin{tabular}{lc}
\hline Parameters & Values for DHF \\
\hline Density ( stem ha-1) & 855 \\
Shannon-Wiener diversity index & 3.18 \\
Species evenness index & 0.79 \\
Margalef's diversity index & 7.57 \\
Simpson's diversity index & 0.07 \\
\hline
\end{tabular}


Table 5. Basal area, number of stems, relative density, relative frequency, relative abundance relative dominance, and Importance Value Index (IVI) for DHF

\begin{tabular}{|c|c|c|c|c|c|c|c|}
\hline Scientific name & $\begin{array}{c}\text { BA } \\
\left(\mathbf{m}^{2} / \mathrm{ha}\right)\end{array}$ & $\begin{array}{c}\text { Ind. } \\
\text { stem no }\end{array}$ & $\begin{array}{l}\text { RA } \\
(\%)\end{array}$ & $\begin{array}{l}\text { RD } \\
(\%)\end{array}$ & $\begin{array}{l}\text { RF } \\
(\%)\end{array}$ & RDo (\%) & IVI \\
\hline$\overline{\text { Acacia auriculiformis }}$ & 7.19 & 289 & 7.18 & 20.13 & 6.26 & 24.64 & 51.02 \\
\hline Acacia mangium & 1.01 & 49 & 1.85 & 3.41 & 4.11 & 3.46 & 10.99 \\
\hline Aegle marmelos & 0.06 & 7 & 0.87 & 0.49 & 1.25 & 0.20 & 1.94 \\
\hline Albizia lebbeck & 0.17 & 9 & 0.87 & 0.63 & 1.61 & 0.57 & 2.81 \\
\hline Albizia procera & 0.58 & 33 & 0.96 & 2.30 & 5.37 & 1.99 & 9.65 \\
\hline Albizia richardiana & 0.57 & 23 & 2.86 & 1.60 & 1.25 & 1.96 & 4.81 \\
\hline Alstonia scholaris & 0.39 & 26 & 1.03 & 1.81 & 3.94 & 1.33 & 7.07 \\
\hline Aphanamixis polystachya & 0.29 & 26 & 1.03 & 1.81 & 3.94 & 0.99 & 6.74 \\
\hline Aporosa wallichii & 0.04 & 6 & 1.74 & 0.42 & 0.54 & 0.14 & 1.10 \\
\hline Aquilaria agallocha & 0.70 & 65 & 3.77 & 4.53 & 2.68 & 2.39 & 9.60 \\
\hline Araucaria cunninghamii & 0.02 & 1 & 0.87 & 0.07 & 0.18 & 0.06 & 0.31 \\
\hline Areca catechu & 0.04 & 3 & 0.87 & 0.21 & 0.54 & 0.14 & 0.88 \\
\hline Artocarpus heterophyllus & 0.40 & 27 & 0.98 & 1.88 & 4.29 & 1.36 & 7.53 \\
\hline Artocarpus lacucha & 0.29 & 19 & 1.03 & 1.32 & 2.86 & 0.98 & 5.16 \\
\hline Averrhoa carambola & 0.13 & 6 & 0.87 & 0.42 & 1.07 & 0.43 & 1.92 \\
\hline Azadirachta indica & 0.37 & 28 & 1.62 & 1.95 & 2.68 & 1.27 & 5.91 \\
\hline Barringtonia acutangula & 0.14 & 11 & 1.06 & 0.77 & 1.61 & 0.46 & 2.84 \\
\hline Bischofia javanica & 0.25 & 16 & 0.99 & 1.11 & 2.50 & 0.85 & 4.47 \\
\hline Bombax ceiba & 0.46 & 22 & 1.13 & 1.53 & 3.04 & 1.59 & 6.16 \\
\hline Borassus flabellifer & 0.08 & 10 & 2.90 & 0.70 & 0.54 & 0.26 & 1.49 \\
\hline Cassia fistula & 0.61 & 22 & 1.59 & 1.53 & 2.15 & 2.10 & 5.78 \\
\hline Chukrasia tabularis & 0.61 & 46 & 1.91 & 3.20 & 3.76 & 2.10 & 9.06 \\
\hline Cryptocarya amygdalina & 0.04 & 3 & 0.87 & 0.21 & 0.54 & 0.12 & 0.86 \\
\hline Dillenia pentagyna & 0.05 & 3 & 0.87 & 0.21 & 0.54 & 0.17 & 0.91 \\
\hline Diospyros blancoi & 0.01 & 1 & 0.87 & 0.07 & 0.18 & 0.02 & 0.27 \\
\hline Elaeis guineensis & 0.16 & 4 & 1.16 & 0.28 & 0.54 & 0.55 & 1.36 \\
\hline Eucalyptus camaldulensis & 2.81 & 97 & 2.56 & 6.76 & 5.90 & 9.61 & 22.27 \\
\hline Ficus hispida & 0.29 & 25 & 1.81 & 1.74 & 2.15 & 0.99 & 4.88 \\
\hline Gmelina arborea & 0.49 & 29 & 2.10 & 2.02 & 2.15 & 1.66 & 5.83 \\
\hline Grewia nervosa & 0.35 & 31 & 3.85 & 2.16 & 1.25 & 1.18 & 4.59 \\
\hline Haldina cordifolia & 0.42 & 25 & 1.81 & 1.74 & 2.15 & 1.44 & 5.33 \\
\hline Lagerstroemia speciosa & 0.09 & 7 & 1.01 & 0.49 & 1.07 & 0.29 & 1.85 \\
\hline Limonia acidissima & 0.08 & 4 & 3.48 & 0.28 & 0.18 & 0.26 & 0.71 \\
\hline Litchi chinensis & 0.08 & 5 & 2.17 & 0.35 & 0.36 & 0.26 & 0.96 \\
\hline Madhuca longifolia & 0.00 & 1 & 0.87 & 0.07 & 0.18 & 0.01 & 0.26 \\
\hline Mallotus philippensis & 0.31 & 40 & 3.16 & 2.79 & 1.97 & 1.06 & 5.81 \\
\hline Mangifera indica & 0.24 & 11 & 3.19 & 0.77 & 0.54 & 0.81 & 2.11 \\
\hline Manilkara zapota & 0.03 & 1 & 0.87 & 0.07 & 0.18 & 0.09 & 0.34 \\
\hline Mimusops elengi & 0.09 & 5 & 1.09 & 0.35 & 0.72 & 0.30 & 1.36 \\
\hline Moringa oleifera & 0.06 & 5 & 0.87 & 0.35 & 0.89 & 0.21 & 1.45 \\
\hline Murraya paniculata & 0.01 & 1 & 0.87 & 0.07 & 0.18 & 0.05 & 0.29 \\
\hline Neolamarckia cadamba & 0.31 & 11 & 0.74 & 0.77 & 2.33 & 1.06 & 4.16 \\
\hline Phoenix sylvestris & 0.01 & 1 & 0.87 & 0.07 & 0.18 & 0.04 & 0.29 \\
\hline Phyllanthus emblica & 0.08 & 4 & 0.87 & 0.28 & 0.72 & 0.26 & 1.25 \\
\hline Psidium guajava & 0.03 & 4 & 1.16 & 0.28 & 0.54 & 0.10 & 0.91 \\
\hline Pterospermum acerifolium & 0.12 & 8 & 2.32 & 0.56 & 0.54 & 0.40 & 1.49 \\
\hline Samanea saman & 1.01 & 18 & 1.96 & 1.25 & 1.43 & 3.45 & 6.14 \\
\hline Shorea robusta & 2.51 & 173 & 7.52 & 12.05 & 3.58 & 8.61 & 24.23 \\
\hline Swietenia mahagoni & 0.53 & 24 & 3.48 & 1.67 & 1.07 & 1.81 & 4.55 \\
\hline Syzygium cumini & 0.01 & 1 & 0.87 & 0.07 & 0.18 & 0.03 & 0.28 \\
\hline Tamarindus indica & 0.37 & 10 & 0.97 & 0.70 & 1.61 & 1.28 & 3.59 \\
\hline Tectona grandis & 3.45 & 97 & 3.51 & 6.76 & 4.29 & 11.81 & 22.86 \\
\hline Terminalia arjun & 0.01 & 1 & 0.87 & 0.07 & 0.18 & 0.02 & 0.27 \\
\hline Terminalia bellirica & 0.19 & 12 & 1.16 & 0.84 & 1.61 & 0.66 & 3.10 \\
\hline Terminalia chebula & 0.61 & 23 & 1.33 & 1.60 & 2.68 & 2.10 & 6.38 \\
\hline Ziziphus mauritiana & 0.02 & 7 & 0.87 & 0.49 & 1.25 & 0.06 & 1.80 \\
\hline Total & 29.27 & 1436 & 100.00 & 100.00 & 100.00 & 100.00 & 300.00 \\
\hline
\end{tabular}

Note: $\mathrm{BA}=$ Basal Area, $\mathrm{RD}=$ Relative Density, $\mathrm{RF}=$ Relative Frequency, RA= Relative Abundance, RDo= Relative Dominance and IVI= Importance Value Index 
Structural composition based on height classes

The vertical profile of a forest provides a clear concept of forest stratification. In the study we assigned six height classes considering total height of the tree individuals of different species with interval of $6 \mathrm{~m}$. The six height classes were, 2- $<7 \mathrm{~m}, 7-<12 \mathrm{~m}, 12-<17 \mathrm{~m}, 17-<22 \mathrm{~m}$, $22-<27 \mathrm{~m}$, and $27-<32 \mathrm{~m}$. The distribution of individuals among different height classes showed a positively skewed curve, indicating a relatively stable population structure and regeneration status. Patterns of height (m) class distribution shows general trends of population dynamics and recruitment process to the maximum species in DHF. It was found that both the number of species and number of individuals decreased regularly with the increasing of total height. Both the number of tree species and number of individuals (56 species; 1436 individuals) were highest in the height range of $7-<12 \mathrm{~m}$ and lowest ( 2 species) in height range of 27-<32 $\mathrm{m}$ (Figure 2).

\section{Vertical structure of some dominant tree species}

Height classes of trees are shown in Figure 3 (A-D) and Figure $3(\mathrm{E}-\mathrm{J})$. Figure $3(\mathrm{~A}-\mathrm{D})$ is the representative of exotic species and Figure $3(\mathrm{E}-\mathrm{J})$ is the representative of native species. The study reveals that exotic species possessed mainly in first four height classes, i.e. Acacia auriculiformis, Acacia mangium, Tectona grandis except for Eucalyptus camaldulensis. However, the maximum height class for exotic tree species was found $2-<27 \mathrm{~m}$ range.

In case of native species, Shorea robusta, Bombax ceiba, and Aquilaria agallocha were found in four height classes whereas Cassia fistula, Azadirachta indica, and Chukrassia tabularis was present in three height classes.

\section{Structural composition based on DBH classes}

The distribution of individuals among different $\mathrm{DBH}$ (cm) classes shows a reverse J-shaped curve (Figure 4). It indicates progressive decrease of tree individuals in larger tree size classes. The number of species and tree individuals was found to decrease with increasing diameter with very little exception. Both the tree species and individuals were maximum (52 species, 534 individuals) in $5-<10 \mathrm{~cm}$ dbh range and minimum (2 species, 4 individuals) in $45-<50 \mathrm{~cm} \mathrm{dbh}$ range (Figure 3). As the $\mathrm{dbh}$ increases, both the number of species and number of tree individuals decrease. It indicates incidence of illegal felling of mature and economically important trees in the area. The higher number of trees in lower size classes also indicates recent initiatives for conservation, protection, and improvement of the forest.

\section{Distribution of some dominant tree species in different diameter classes}

Diameter classes of trees are shown in Figure 5 (A-D) and Figure $5(\mathrm{E}-\mathrm{J})$. Figure $5(\mathrm{~A}-\mathrm{D})$ is representative of exotic species and Figure 5 (E-J) is the representative of native species. In case of native species, Shorea robusta and Terminalia chebula, Cassia fistula, Alstonia scholaris were found in maximum dbh class with the highest density in the first and second class decreasing with increasing dbh class forming inverted $\mathrm{J}$ shape.

In case of exotic species, the diameter class distribution of Acacia auriculiformis, Acacia mangium, Shorea robusta, Eucalyptus camaldulensis, etc. showed a reverse shape J-curve with a sharp drop in the higher diameter classes. The sharp decline and very low representation in the higher diameter classes depict illegal felling in the DHF. The presence of some large trees and the prevalence of small to medium size individuals also represent that the forest is in a second development stage.

\section{Hierarchical cluster based on the dominant tree species in the Durgapur hill forest}

The study revealed tree species of DHF are grouped into four hierarchical clusters (Figure 4). Acacia auriculiformis was the most dominant species followed by Shorea robusta, Tectona grandis, Eucalyptus camaldulensis and the member of first cluster. Then Samanea saman, Cassia fistula, Haldina cordifolia, Gamlina arborea, etc. were the second most dominant species and the member of second cluster. Other species under this research form rest of the clusters (Figure 4). However, it is obvious that the dominated tree are exotic species. This indicates that the area is gradually converted with plantation activities.

\section{Discussion}

Floral inventory is a prerequisite for fundamental research in community ecology, and for modeling patterns of species diversity and understanding species distribution patterns (Das et al. 2018). The tree species composition of DHF (56 tree species, 50 genera, 29 families) is closer to that found in tropical forests, for example, 50 tree species in Rampahar Natural Forest Reserve (Chowdhury et al. 2018a), 52 tree species in Kaptai National Park (Rahman et al. 2016), 62 tree species in Tankawati natural forest (Motaleb and Hossain 2011). However, DHF possessed lower tree species in comparison to 107 tree species in Kamalachari natural forest, Rangamati and Bandarban borderline (Hossain et al. 2015), 153 tree species in Tropical Forest of Eastern Ghats, India (Reddy et al. 2011) and 93 tree species in Chunati Wildlife Sanctuary (Nath et al. 2016).

As plantation activities are increasing in study area, the stem density (855 stems ha ${ }^{-1}$ ) is higher than 709 stems ha $^{-1}$ in tropical forest of Eastern Ghats, India (Reddy et al. 2011). But the number is lower than a study by Haider et al. (2013) in natural forests of Moulvibazar in Sylhet Forest Division where they recorded 1,051 tree individuals per ha, belonging to 81 species, 59 genera and 33 families. The basal area $\left(29.27 \mathrm{~m}^{2} \mathrm{ha}^{-1}\right)$ of DHF is lower than that of 47.02-62.16 $\mathrm{m}^{2} \mathrm{ha}^{-1}$ in Tankawati natural forest of Chittagong South Forest Division (Motaleb and Hossain 2011). Besides, it is higher than $16.88 \mathrm{~m}^{2} \mathrm{ha}^{-1}$ revealed by Rahman et al. (2000) and $21.10 \pm 2.62 \mathrm{~m}^{2} \mathrm{ha}^{-1}$ found by Hossain et al. (2015). The moderate number of tree species with higher stem density but lower basal area indicates that the forest area is suffering from deforestation. 
The IVI value indicates a complete picture of phytosociological character of a species in the community. The study showed that the most dominant 10 species have $58 \%$ of the total IVI (174.29 out of 300), where the dominant tree species were Acacia auriculiformis, Shorea robusta, Alstonia scholaris Tectona grandis, etc. However, Hossain et al. (2015) showed that the most dominant 10 species have $34.67 \%$ of the total IVI (104 out of 300) and the amount is less than present findings.

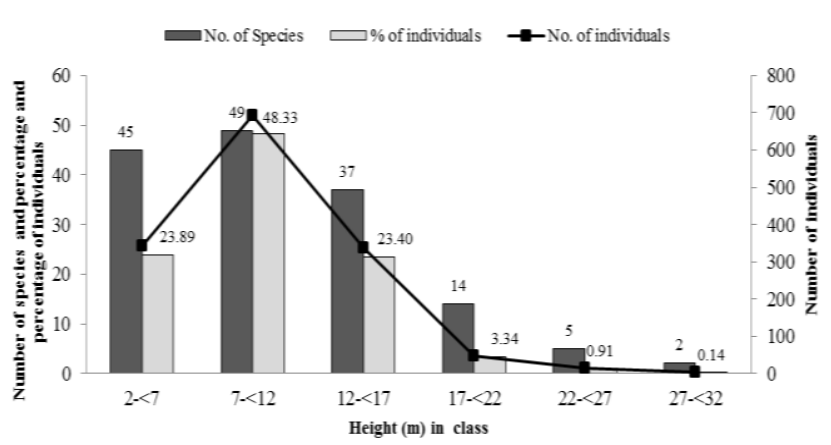

Figure 2. Distribution of tree species, $\%$ of tree individuals and individual number in different height $(\mathrm{m})$ classes of DHF

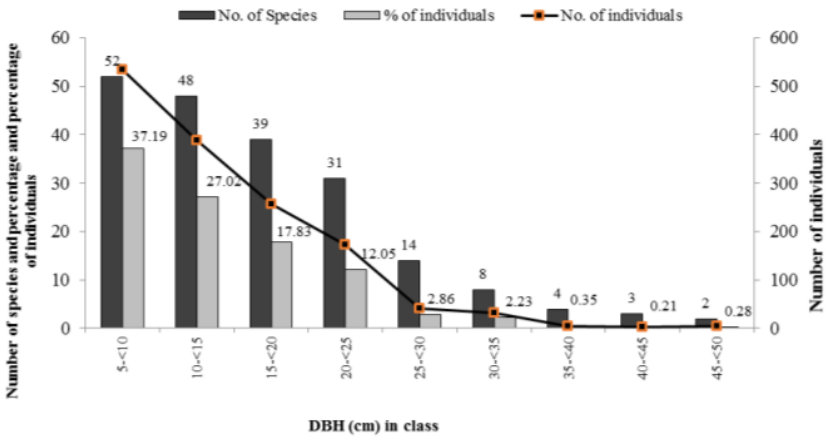

Figure 4. Distribution of tree species, $\%$ of tree individuals and individual number in different DBH $(\mathrm{cm})$ classes of DHF

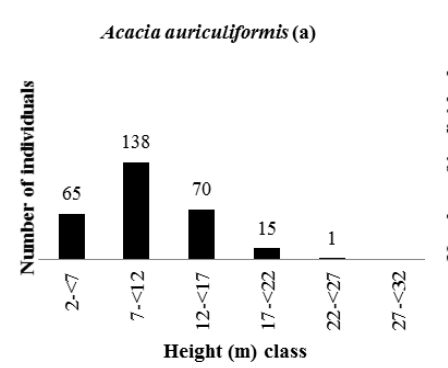

A

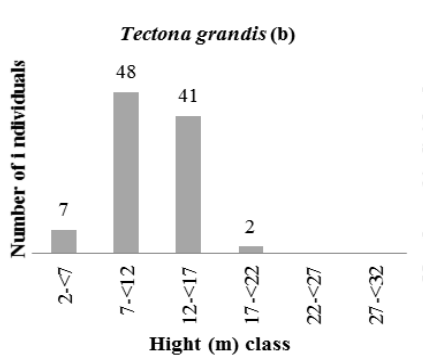

B

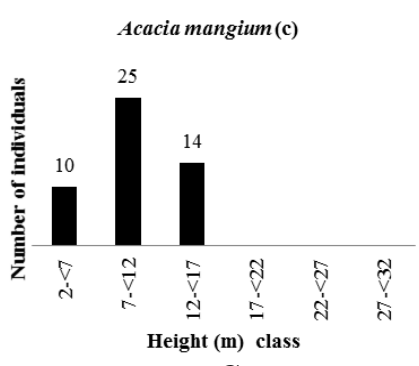

C

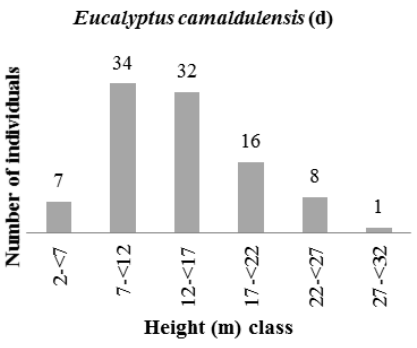

D

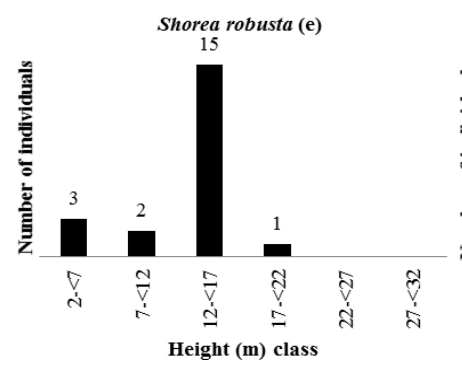

E
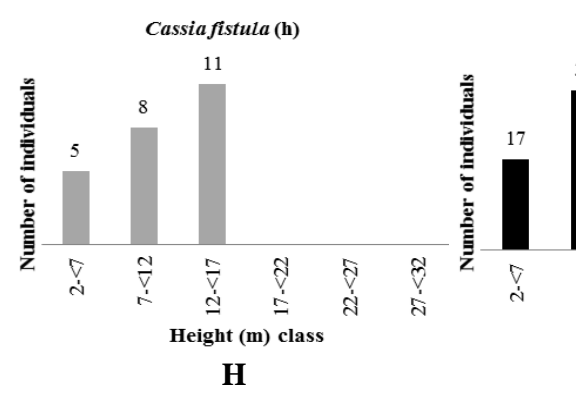

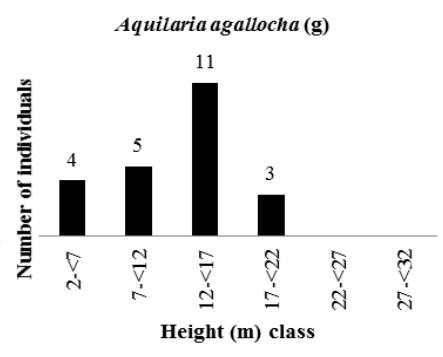

G

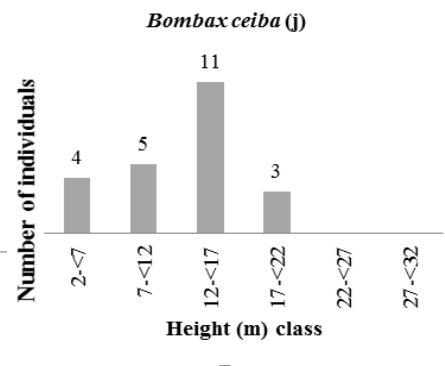

J

Figure 3. A-D. Height class distribution of some exotic tree species in DHF. E-J. Height class distribution of some native tree in DHF 


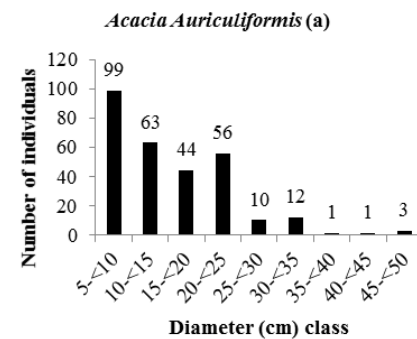

A

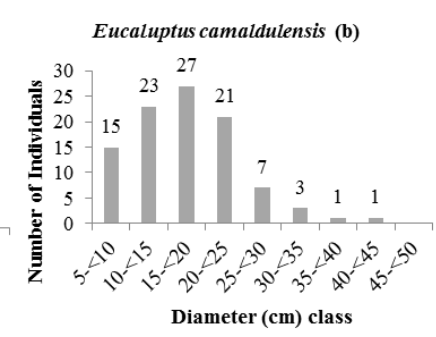

B

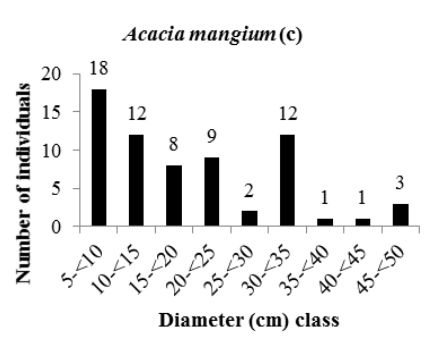

C

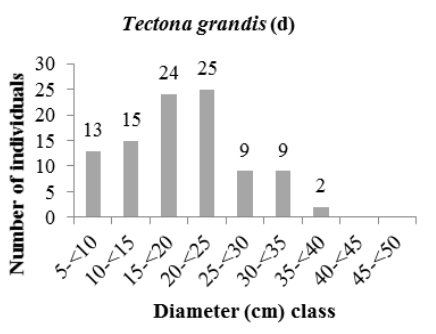

D

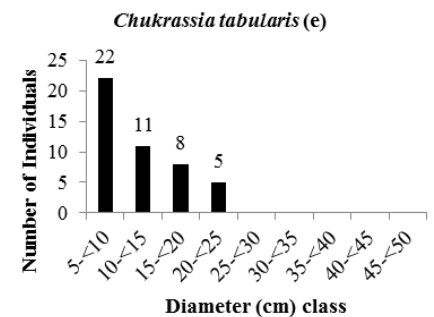

E

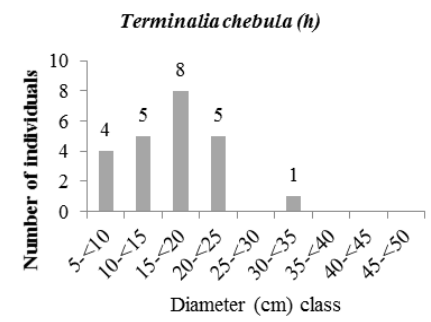

H

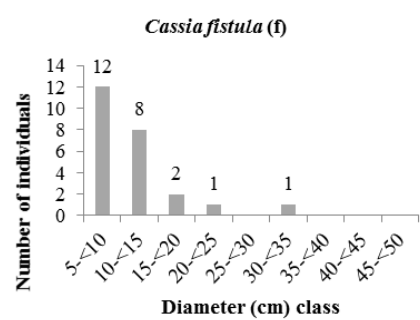

F

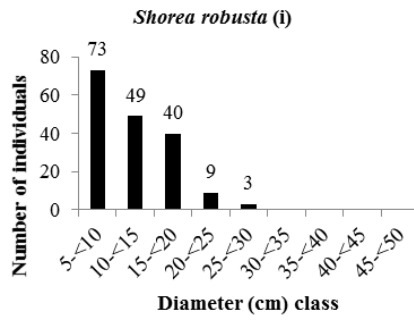

I

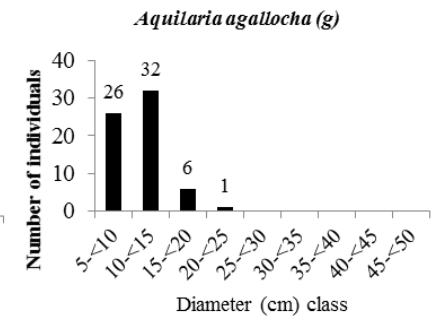

G

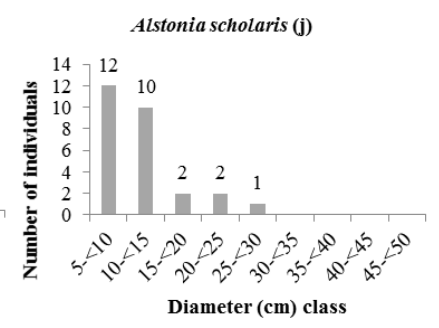

J

Figure 5. A-D. Diameter $(\mathrm{cm})$ class distribution of some exotic tree species in DHF. E-J. Diameter $(\mathrm{cm})$ class distribution of some dominated tree species in DHF

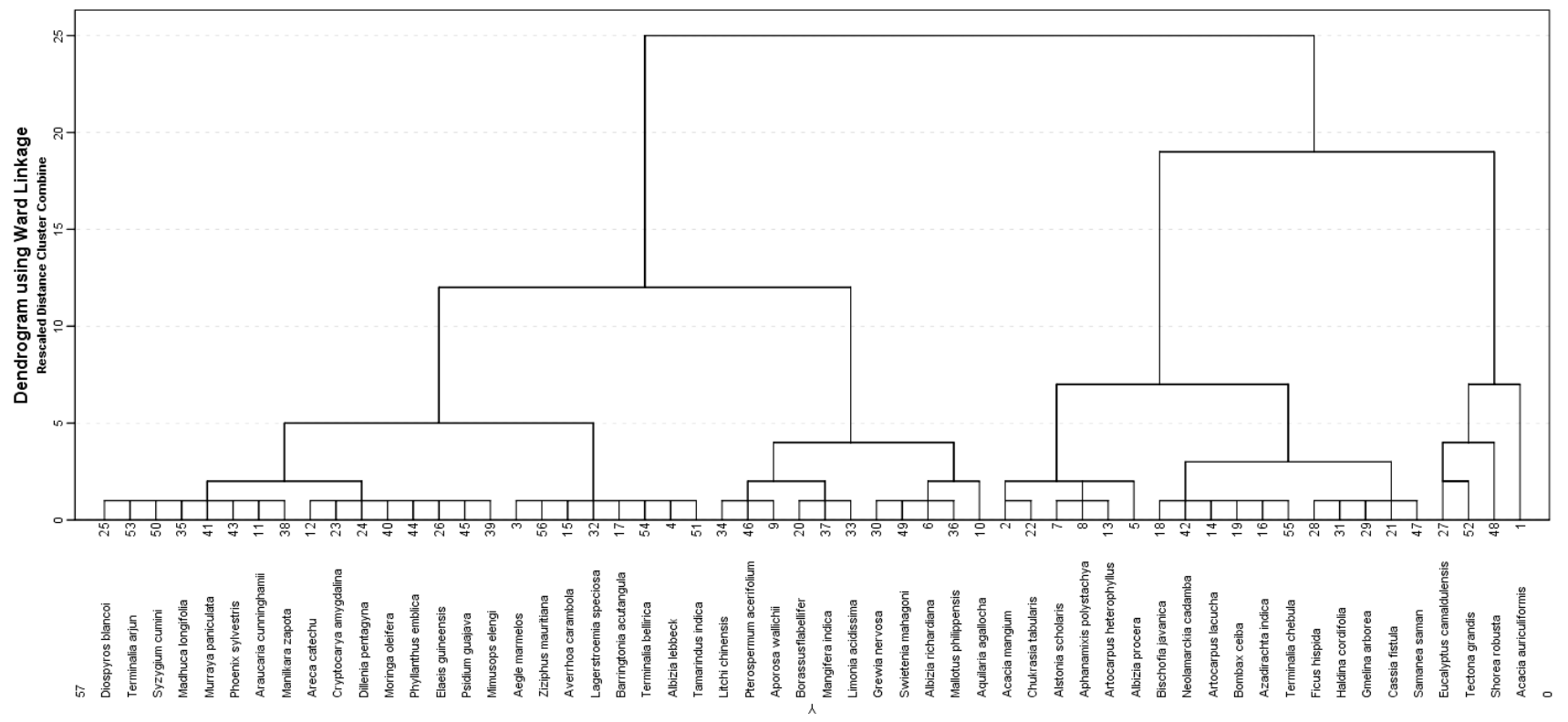

Figure 4. Hierarchical cluster of the tree species in DHF 
The maximum number of species (52) and percentage of tree individuals $(37.19 \%)$ was found in the DBH range of $0.5-<10 \mathrm{~cm}$, whereas the maximum number of species (88) and percentage of tree individuals $(66.02 \%)$ was found in the DBH range of $10.1-<20 \mathrm{~cm}$ in Kamalachari natural forest of Chittagong south forest division (Hossain et al. 2015 ) and nearly $90 \%$ trees were belonging to $5-$ to $15-\mathrm{cm}$ dbh class recorded form Chunati Wildlife Sanctuary (Nath et al. 2016). Besides, DBH range of $20.1-<30 \mathrm{~cm}$ possessed both highest ( 58 species) number of species and percentage $(29.69 \%)$ of tree individuals in Tankawati Natural Forest Reserve of Chittagong (South) Forest Division, Bangladesh (Motaleb and Hossain 2009). Again, Hossain et al. (2015) revealed the number of tree species, tree individual percentage, and their number were highest (97 species, $77.99 \%, 404$ individuals) in the height range of 4.5-14.4 m. Present study found that Eucalyptus camaldulensis, Areca catechu, Averrhoa carambola, Elaeis guineensis, Tamarindus indica, Terminalia bellirica, Neolamarckia cadamba dominated the upper canopy. The height class distribution indicates that Durgapur hill forest is a relatively well-stratified forest.

The Shannon-wiener diversity index of 3.18 is lower than that of 3.25 in Tankawati natural forest of Chittagong (South) Forest Division, 4.01 in Komolchori VCF of Khagrachari (Chowdhury et al. 2018) and 4.27 in Garo Hills of India (Kumar et al. 2006) where, but is very closely related with Chunati Wildlife Sanctuary (3.15) (Nath et al. 2016). Margalef's index (7.57), lower value of Simpson's index (0.07) and Species evenness index (0.79) indicate less species diversity in DHF in comparison to other natural forests of the country. However, it is alarming that the forest area is now dominated by some exotic species which should be rejuvenated with the native flora.

In conclusion, the study revealed that Durgarpur hill forest had a moderately diverse tree species along with stratified tree populations. The IVI values revealed economically and ecologically most important tree species in the forest and those to be prioritized for conservation. The height class distribution indicates occurrences of illegal removal of trees from the forest. The dbh class distribution shows that some species are in poor regeneration status may be due to human disturbance and livestock grazing. Collection of sun-grass, intentional burning, and encroachment caused extensive loss of regenerated seedlings of important native tree species in the last decades. It is therefore recommended to establish some Permanent Sample Plots and Assisted Natural Regeneration plots, and adopt species-specific conservation measures to enhance regeneration status and tourism potentials of DHF. Special conservation measures both ex-situ and in-situ methods may be initiated to conserve the rare native plant species in this area. Improved law and policy, livelihoods and incentives and capacity building may be considered for the area adjacent people. Also, regular community patrolling should be done to stop the theft of valuable timber. Different encroachments like inhabitation, agricultural expansion, hunting, shooting, illegal cutting, fuelwood collection, etc. were seen in the forest during field data collection. Therefore, such detrimental activities must be stopped immediately, otherwise, those will make the area more fragmented and reduce natural forest restoration capacity.

\section{ACKNOWLEDGEMENTS}

The authors cordially acknowledge the Forest Department for their co-operation and support in the field works. The authors are highly thankful to taxonomist of Bangladesh Forest Research Institute (BFRI) and Institute of Forestry and Environmental Sciences, University of Chittagong, for identification of the plant samples of DHF. This research did not receive any specific grant from funding agencies in the public, commercial, or not-forprofit sectors. Besides, the authors declare that they have no competing interests.

\section{REFERENCES}

Ahmed ZU, Begum ZNT, Hassan MA, Khondker M, Kabir SMH, Ahmad M, Ahmed ATA, Rahman AKA, Haque EU. (eds.). 2008. Encyclopedia of Flora and Fauna of Bangladesh, vol. 5-12. Asiatic Society of Bangladesh, Dhaka.

Bangladesh Bureau of Statistics (BBS). 2013. District Statistics 2011, Netrokona. Bangladesh Bureau of Statistics, Dhaka.

Caratti JF. 2006. Cover/Frequency (CF) Sampling Method. USDA Forest Service Gen. Tech. Rep. RMRS-GTR-164-CD. p 15. http://www.fs.fed.us/rm/pubs/rmrs_gtr164/rmrs_gtr164_ 08_cover_freq.pdf. [17 Jan 2015].

Chowdhury B, Hossain MK, Hossain MA, Khan BM. 2018a. Native tree species diversity of Rampahar Natural Forest Reserve in Rangamati South Forest Division, Bangladesh. Ceylon J Sci 47 (2): 129-136. DOI: $10.4038 /$ cjs.v47i2.7508

Chowdhury MA, Islam KN, Hafiz N, Islam K. 2018b. Diversity of trees in a community-managed forest: the case of Komolchori VCF, Khagrachari, Bangladesh. Geol Ecol Landsc. DOI: 10.1080/24749508.2018.1508980

Dallmeier F, Kabel M, Rice R. 1992. Methods for long-term biodiversity inventory plots in protected tropical forests. In: Dallmeier (ed.). Long-term monitoring of biological diversity in tropical forest areas methods for establishment and inventory of permanent plots, MAB digest II, UNESCO, Paris.

Das SC, Alam MS, Hossain MA. 2018. Diversity and structural composition of species in dipterocarp forests: a study from Fasiakhali Wildlife Sanctuary, Bangladesh. J For Res 29 (5): 1241-1249. DOI: 10.1007/s11676-017-0548-7

Feeroz MM, Uddin MZ. 2015. Biodiversity of Nijhum Dweep National Park. Bangladesh Forest Department, Dhaka, Bangladesh.

Haider MR, Rahman MM, Khair A, Islam SMZ. 2013. Composition and diversity of tree species in Moulvibazar natural forests of Sylhet Forest Division, Bangladesh. Bangladesh J For Sci 32 (2): 49-60.

Hossain MA, Hossain MK, Salam MA, Rahman S. 2013. Composition and diversity of tree species in Dudhpukuria-Dhopachori Wildlife Sanctuary of Chittagong (south) forest division, Bangladesh. Res J Pharmaceut Biol Chem Sci 4 (2): 1447-1457.

Hossain MA, Hossain MK, Alam MS, Mamun MMAL. 2017. Structural Composition and Distribution of Tree Species of DudhpukuriaDhopachari Wildlife Sanctuary, Chittagong, Bangladesh. J Biodiv Conserve Bioresour Manag 3 (1): 17-30. DOI: 10.3329/jbcbm.v3i1.36757

Hossain MA, Hossain MK, Alam MS, Uddin MM. 2015. Composition and Diversity of Tree Species in Kamalachari Natural Forest of Chittagong South Forest Division, Bangladesh. J For Environ Sci 31 (3): 192-201. DOI: 10.7747/JFES.2015.31.3.192

Hossain MA, Hossain MK, Salam MA, Rahman S. 2013. Composition and diversity of tree species in Dudhpukuria-Dho-Pachori Wildlife Sanctuary of Chittagong (south) forest division, Bangladesh. Res J 
Pharmaceut Biol Chem Sci 4: 1447-1457. DOI: 10.7747/JFES.2015.31.3.192

Hossain MK, Hossain M, Alam MK. 1997. Diversity and structural composition of trees in Bamu reserved forest of Cox's Bazar forest division, Bangladesh. Bangladesh J For Sci 26: 31-42.

Hossain MK. 2001. Overview of the forest biodiversity in Bangladesh. In Assessment, conservation and sustainable use of forest biodiversity (CBD Technical Series no. 3). Secretariat of the Convention on Biological Diversity, Montreal, SCBD, Canada.

Kumar A, Marcot BG, Saxena A. 2006. Tree species diversity and distribution patterns in tropical forests of Garo Hills, India. Curr Sci 91 (10): 1370-1381.

Malaker JC, Rahman MM, Azad-ud-doula Prodhan AKM, Malaker SK, Khan MAH. 2010b. Floristic Composition of Madhupur Sal Forest in Bangladesh. J Soil Nature 4 (1): 25-33.

Margalef R. 1958. Information Theory in Ecology. General Systematics 3 : 36-71.

Misra R. 1968. Ecology Workbook. Oxford and IBH Publishing. New Delhi, India.

Moore PD, Chapman SB. 1986. Methods in Plant Ecology. Blackwell Scientific Publications, Oxford.

Motaleb MA, Hossain MA. 2009. Studies on the Structural Composition Based on Diameter Class Distribution of Semi-Evergreen Natura Forest of Chittagong (South) Forest Division, Bangladesh. EcoFriendly Agric J 2 (10): 825-829.

Motaleb MA, Hossain MK. 2011. Assessment of tree species diversity of Tankawati natural forests, Chittagong (South) Forest Division, Bangladesh. Eco-Friendly Agric J 4 (2): 542-545.

Nath TK, Hossain MK, Alam MK. 1998. Diversity and composition of trees in Sitapahar forest reserve of Chittagong Hill Tracts (South) Forest Division, Bangladesh. Ann For 6 (1): 1-9.

Nath TK, Hossain MK, Alam MK. 2000. Assessment of tree species diversity of Sitapahar Forest Reserve, Chittagong Hill Tracts (South) Forest Division, Bangladesh. Indian For 126 (1): 16-21.

Nath TK, Jashimuddin M, Kamruzzaman M, Mazumder V, Hasan MK, Das S, Dhali PK. 2016. Phytosociological characteristics and diversity of trees in a co-managed protected area of Bangladesh: Implications for conservation. J Sustain For 35 (8): 562-577. DOI $10.1080 / 10549811.2016 .1231615$
Nur A, Nandi R, Jashimuddin M, Hossain MA. 2016. Tree Species Composition and Regeneration Status of Shitalpur Forest Beat under Chittagong North Forest Division, Bangladesh. Adv Ecol 2016: 5947874. DOI: $10.1155 / 2016 / 5947874$.

Pielou EC. 1966. Species diversity and pattern diversity in the study of ecological succession. J Theor Biol 10: 370-383. DOI: 10.1016/00225193(66)90133-0

Rahman MM, Mahmud MAA, Shahidullah M, Nath TK, Jashimuddin M. 2016. The competitiveness of the phytosociological attributes of the protected areas in Bangladesh with that in the other tropical countries. J Sustain For 35 (6): 431-450. DOI: 10.1080/10549811.2016.1202841

Rahman MR, Hossain MK, Hossain MA, Haque MS. 2017. Floristic Composition of Madhupur National Park, Tangail, Bangladesh. Bangladesh Agric 7 (1): 27-45.

Rankin-de-Merona JM, Prance GT, Hutching RW, Silva MF, Rodrigues WA, Uehiling ME. 1992. Preliminary Results of a large-scale Tree Inventory of Upland Rain Forest in the Central Amazon. Acta Amazonica 2: 493-534. DOI: 10.1590/1809-43921992224534

Reddy CS, Barbar SM, Amarnath G, Pattanaik C. 2011. Structure and floristic composition of tree stand in tropical forest in the Eastern Ghats of Northern Andhra Pradesh, India. J For Res 22 (4): 491-500. DOI: 10.1007/s11676-011-0193-5

Reddy CS, Shilpa B, Giriraj A, Reddy KN, Rao KT. 2008. Structure and floristic composition of tree diversity in tropical dry deciduous forest of Eastern Ghats, Southern Andhra Pradesh, India. Asian J Sci Res 1: 57-64. DOI: $10.3923 / a j s r .2008 .57 .64$

Sajib NH, Uddin SB, Islam MS. 2016. Vascular Plant Diversity and their Distribution Pattern in Sandwip Island, Chittagong, Bangladesh. J. Biodivers Manag For 5 (2): 1-5. DOI: 10.4172/2327-4417.1000159

Shannon CE, Wiener W. 1963. The Mathematical Theory of Communities. University of Illinois Press, Urbana, IL.

Shukla RS, Chandel PS. 2000. Plant Ecology and Soil Science ( $9^{\text {th }}$ ed.). Ramnagor S. Chand and Company Limited, New Delhi.

Siddiqui KU, Islam MA, Ahmed ZU, Begum ZNT, Hassan MA, Khondker M, Rahman MM, Kabir SMH, Ahmed M, Ahmed ATA, Rahman AKA, Haque EU. (eds.). 2007. Encyclopedia of Flora and Fauna of Bangladesh, Vol. 11. Angiosperms: (AgavaceaeNajadaceae). Asiatic Society of Bangladesh, Dhaka.

Simpson EM. 1949. Measurement of diversity. Nature 1949: 163-688. DOI: $10.1038 / 163688 \mathrm{a} 0$ 